To be published in On Philosophy in AMERICAN LaW, Francis J. Mootz, III., ed. (Cambridge Univ. Press 2008).

\title{
Critical Legal Theory Today
}

\author{
Jack M. Balkin ${ }^{1}$
}

Among the many topics in the philosophy of law one has always been central to me: the relationship between law and justice. Law does many things: It creates institutions, facilitates transactions, gives incentives for socially beneficial behavior, deters misconduct, manufactures social realities. But one thing law does especially is legitimate power, both just power and unjust power. Law's ability to legitimate is the source of the nested opposition between law and justice. Law is never perfectly just- indeed, it is often not very just at all. And yet it is an indispensable condition for justice.

"Legitimate," like "sanction," is a Janus word, one that refers simultaneously to a concept and its opposite. To "legitimate" means to bring power under the rule of law so that it is (sufficiently) just, impartial, or otherwise worthy of respect. But to "legitimate" also means to apologize for or mystify the exercise of power so that it seems to be just, impartial and worthy of respect whether or not that is so.

The dual nature of "legitimate" is the central concern of a critical theory of law. Critical theories ask how law legitimates power in both senses of the word: how it shapes, channels and restrains power and how it mystifies, disguises, and apologizes for it. In addition, a critical theory of law asks how the very acts of making, interpreting and applying law - and thus of legitimation in both senses - produce and proliferate ever new forms of power, both just and unjust.

You might think that a critical theory would focus primarily on law's ideological effects. But there is more to it than this. First, a critical theory must be as concerned with how law might succeed in furthering justice as it is with how law disguises injustice. Second, older Marxist-inspired models of ideology as obfuscation or distortion hardly do justice (pardon the pun) to law's versatile powers of legitimation. Law does not merely mask or apologize for power, nor does it merely restrain it. Instead, law creates ever new forms and methods for

\footnotetext{
${ }^{1}$ Knight Professor of Constitutional Law and the First Amendment, Yale Law School. My thanks to Mary Dudziak, Bob Gordon, Sandy Levinson, Linda Meyer, Matthew Palmer, Mike Seidman and Mark Tushnet for their comments on previous drafts.
} 


\section{Critical Legal Theory Today}

exercising power. Here Foucault's model of social relations is at least as important as Marx's. Law proliferates power by making itself true in the world. It generates new institutions, new conventions, and new social realities, and it generates new forms of professional knowledge about all of them. It shapes the imagination of those who live under it around the categories and institutions that it produces. Law does not simply distort the world - or even merely represent it correctly; rather it makes a world, one in which and through which we live, act, imagine, desire and believe. ${ }^{2}$

A critical theory views law ambivalently as a method for legitimating (in both senses of that wondrous word) the exercise of power in society. The word "ambivalence" comes from the Latin; it means having strength or effects on both sides. (And hence, this dual effect often produces mixed emotions). We should distinguish an ambivalent conception of law from a pejorative conception. ${ }^{3} \mathrm{~A}$ pejorative conception views law fundamentally as an ideological practice for mystifying and legitimating injustice. By contrast, an ambivalent conception of law means that we see both the beneficial and harmful aspects of law - both law's ability to further its purported goal of a just social order and its ability to fall away from that goal and to mystify and apologize for that failure. Law may offer an unjust and unwieldy system for apprehending, incarcerating, and destroying human beings. It may also offer important elements of procedural fairness, equality and human dignity. It does both of these things simultaneously, and it may be difficult to fully separate its harmful and beneficial aspects in practice. Justice and injustice, responsiveness to the world and mystification, are often inextricably bound together. In the pejorative conception, law is simply idolatry, a confused and contradictory mode of discourse, a technique of apology and disguise. In the ambivalent conception, law is both ideology and promise; it can be one resource among others in a project of political redemption.

Critical legal theorists of the 1970s and 1980s asked whether law was a kind of politics, and whether the discourse of rights was beneficial or harmful to justice and human flourishing. When people speak of the relationship between law and "politics," they mean law's relationship to the many different forms of power - economic, social, cultural, political, military and technological - that law might constrain, enable, or propagate. They also mean the ideals, ideologies and arguments that people use to justify these forms of power. "Politics" refers to people's contrasting visions and to the values that they want to realize or

\footnotetext{
${ }^{2}$ See Jack M. Balkin, The Proliferation of Legal Truth, 26 Harv. J. LAW \& Pub. POL'Y 5 (2003).

${ }^{3}$ See J.M. BALKin, Cultural SofTWARE: A THEORY OF IDEOLOGY (1998)(contrasting ambivalent and pejorative conceptions of ideology).
} 


\section{Critical Legal Theory Today}

recognize in public life. But it also refers to the power to realize or recognize those values and visions. So when we consider the relationship between "law and politics" we are also interested in the question of law and power - how people justify and legitimate power - either directly or indirectly - through law. And we must also account for law's own methods of proliferating its own power, whether it be through legal concepts, legal institutions, legal culture, legal education, legal officers, or the legal profession.

In any case, law is not simply politics; rather it is a surprisingly plastic medium of discourse about power and for the exercise of power. Law mediates, colonizes, and transforms political and cultural struggle into legal doctrines and legal disputes, and in doing so, constructs a new kind of power-the power of legal knowledge and institutions - that hopes to become indispensable to every other form. Law spreads and is implemented through institutions and practices that call on law or depend on law, and through a professional culture that treats law as of the highest importance, indeed, as central to civilization itself. Through legal arguments and legal institutions political struggle and ideological disagreement become refracted and displaced, only to resurface in ever new guises. Legal institutions and legal argument facilitate the exercise of power (and struggles over power) while tempering and redirecting them. Law simultaneously channels and facilitates, restrains and multiplies the different forms of power in society - whether economic, social, cultural, political, military or technological - while proliferating its own forms of power, its own professional culture and its own authority. This complicated relationship between law and power is law's relative autonomy.

Three decades ago, critical legal scholars saw relatively little value in law's relative autonomy. They pointed out that if law were only relatively autonomous in this way, law would usually tend to reflect the most powerful interests in society at the expense of weaker interests. Worse yet, legal institutions and legal arguments would disguise this phenomenon, attempting to show that injustices committed in the name of law were required by legal reasoning, by legal impartiality, by procedural regularity and by the values inherent in the rule of law. Law would contribute to and apologize not only for the dominant forms of power in society, but also for many different forms of subordination and injustice.

The argument was twofold. First, legal rhetoric often mystifies and legitimates injustice perpetrated through law. Second, despite the surface appearance of reasoned elaboration, procedural regularity and impartiality, legal reasoning is often indeterminate or under-determinate. More precisely, 


\section{Critical Legal Theory Today}

substantial parts of the law or aspects of the law (like procedure and fact-finding) are sufficiently open textured in enough areas and on enough questions that clever lawyers and judges can often reshape its doctrines or its application with sufficient cognitive effort. By generating new ways of interpreting laws and precedents, by jousting over application and procedure, and by describing and redescribing the facts, the most powerful forces in society can often shape the practical force of law largely to their liking. They can do this both in terms of the substantive content of legal doctrines and in terms of how they would be applied to facts - as the law found and interpreted those facts. Even if doctrine is clear, application may be contested, even if application is straightforward, fact-finding can be controverted, even where the facts are clear, procedural hurdles can be erected. All other things being equal, the most powerful groups and individuals tend to enjoy greater success in shaping the content, force and application of law because they often enjoy greater access to lawmakers, courts and quality legal counsel, because they can devote more resources to legal representation and lobbying, or because they can afford to make systematic and strategic use of the legal system over extended periods of time.

Because lawyers' and judges' rhetorical efforts can take advantage of law's many opportunities for innovation and contestation, the practical effect of legal rules and their application tends toward the vector sum of the different modes of power in society. The most powerful forces generally make the greatest use of law; they will tilt the substantive content of law to their interests, or, failing that, the way that the law is applied and enforced in practice. Conversely, the substantive content of law often proves least helpful to the least powerful groups; and often will be applied and enforced in practice to their relative detriment. Oliver Wendell Holmes, Jr., speaking of his career as lawyer and judge, once said that his epitaph should read "Here lies a supple tool of power." ${ }^{4}$ Critical scholars might argue that Holmes' epitaph describes not only his career but the entire legal system. Law - even a relatively autonomous law - is a supple tool of power.

Critical theory's concern with law's under-determination and plasticity captures only half the story. Indeed, there is no necessary correlation between indeterminacy and illegitimacy. Law's plasticity and indeterminacy might help disguise and mystify injustices, but they might also promote adaptability and facilitate progress. A determinate law might avoid manipulation by powerful interests. But determinate legal norms - even when applied impartially - can be substantively unfair or tilted toward the interests of the powerful. Determinacy foments injustice as much as indeterminacy ever did if the rules are unjust rules,

\footnotetext{
${ }^{4}$ Yosal Rogat, The Judge as Spectator, 31 U. CHI. L. REV. 213, 249-50 (1964) (quoting Holmes).
} 
or if they tilt inequitably toward some groups over others.

Perhaps even more important, implicit in the idea of law's relative autonomy is a contrary point. Even if law is a supple tool of power, law also serves as a discourse of ideas and ideals that can limit, channel and transform the interests of the powerful, sometimes in unexpected ways that the powerful can not fully control. Law is a tool of power that can become important and even indispensable to power. People have to justify what they want to do through it. Perhaps the tools of law can not fully dismantle the forces of injustice. But the proliferation of law and legal institutions also shapes and constrains how people can justify their actions and what they can do, both for good and for ill. In this way law and legal culture-- as technologies and methods of justifying and shaping power-- also become political resources for limiting and channeling what powerful people and institutions can do.

The relative autonomy of law from politics - rather than its complete autonomy - simultaneously poses a threat and a promise. The threat is that law will fail to do much more than ratify and legitimate the interests of the powerful; the promise is that it might hold off the worst excesses of power by giving people discursive and institutional tools to talk back to power, to restrain its selfishness and inhumanity, and to imagine finer, better visions of human association.

The threat and the promise of law are joined together inseparably. What gives law its power to legitimate is its ability to re-describe unjust and unfair events, social practices and institutions in terms of valued ideals of human association like consent, freedom, dignity, equality and fairness. In the hands of lawyers and politicians, law can disguise, mystify and legitimate great injustices using the very ideas and ideals we admire. But law can only do this because it appeals to these values and claims to try to put them into practice through law. Recourse to law forces the powerful to talk in terms in which the powerless can also participate and can also make claims.

From this standpoint, law is not simply an efficient tool of power that powerful people and powerful groups can wield any way they like. They do not merely shape the world with it; rather it shapes them and their world, because they have bought into law as a means of achieving and wielding power. Law shapes their beliefs and desires, their sense of the appropriate and the inappropriate, their conceptions of the possible and impossible. Law generates its own institutions and its own demands; it creates its own culture, it is its own form of life; it struggles with other forms of knowledge and power for dominance. That struggle might lead to yet another form of professional power displacing 


\section{Critical Legal Theory Today}

older ones. But it might offer a space for something far more beneficial and noble.

The critical approach to law — or at any rate, my version of it—has always been doubled, has always reflected the Janus word "legitimate." On the one hand, powerful people have used law to subordinate others and secure their own interests under the guise of promoting laudable goals like freedom, equality, liberty, consent, community and human dignity. On the other hand, by choosing to speak in the language of law, powerful people and interests can sometimes be called to account because they try to legitimate what they are doing in those terms. The people they take advantage of can argue that this is a misuse of law, an illegitimate attempt at mystifying rhetoric. They can appeal to the values that law seeks to protect to promote better, more just, and more humane practices and forms of human association.

Important theoretical debates among critical scholars in the 1970s and 1980s period revolved around which conception of law was the best one. Some critical scholars adopted a largely pejorative conception, focusing primarily on law's defects. They argued that the rule of law was enmeshed in irreconcilable contradictions; they denounced rights talk as sterile, useless and counterproductive. ${ }^{5}$ Others, especially feminist and critical race theory scholars, pointed out that rights discourse and rule of law values were among the few resources that disempowered people had. ${ }^{6}$ Rule of law and rights talk were potentially emancipatory discourses. They held a limited but important potential for liberation and for contesting the arbitrary and unjust use of power.

These feminist and critical race theorists understood the deemphasized

\footnotetext{
${ }^{5}$ The most famous account is Mark V. Tushnet, An Essay on Rights, 62 TEX. L. REV. 1363 (1984); see also Morton J. Horwitz, Rights, 23 HARV. C.R.-C.L. L. REV. 393 (1988); Frances Olsen, Statutory Rape: A Feminist Critique of Rights Analysis, 63 TEX. L. REV. 387 (1984); Peter Gabel, The Phenomenology of Rights Consciousness and the Pact of the Withdrawn Selves, 62 TEX. L. REV. 1563 (1984); Duncan Kennedy, The Structure of Blackstone's Commentaries, 28 BufF. L. REV. 205 (1979); for a retrospective and renewed defense of the critique of rights, see Duncan Kennedy, A CRitique of AdJudication (Fin de SieCle) 315-338 (1997); Duncan Kennedy, “The Critique of Rights in Critical Legal Studies,” in LEFT LEGALISM/LEFT CRITIQUE 178 (Wendy Brown \& Janet Halley eds., 2002).

${ }^{6}$ Kimberle W. Crenshaw, Race, Reform, and Retrenchment: Transformation and Legitimation in Anti-Discrimination Law, 101 HARV. L. REV. 1331 (1988); Patricia S. Williams, Alchemical Notes: Reconstructing Ideals from Deconstructed Rights, 22 HARV. C.R.-C.L. L. REV. 401 (1987); Matsuda, Looking to the Bottom: Critical Legal Studies and Reparations, 22 HARV. C.R.C.L. L. REV. 323 (1987); Elizabeth M. Schneider, The Dialectic of Rights and Politics: Perspectives From the Women's Movement, 61 N.Y.U. L. REV. 589 (1986).
} 


\section{Critical Legal Theory Today}

elements - the other side - of critical claims about the relative autonomy of law. They well recognized that rule of law values and rights discourse were hardly perfect - after all, they had been used repeatedly to justify slavery and the subordination of women - but that they had also allowed people to speak out against and to restrain the worst excesses of power. Even in a period of deep skepticism and disillusionment about what law could do, these critical scholars retained a sense of the political importance of rule of law values and rights discourse. That is not because they believed in a strict autonomy of law from politics, but because they understood the political values that legal culture and rights discourse might serve.

The best version of critical theory, I think, employs an ambivalent conception of law rather than a pejorative conception: it recognizes law's relative autonomy from other forms of power in social life, and it understands the dual or Janus-faced nature of that relative autonomy. It sees both law's limitations in the face of power and its possibilities as a means of channeling power and preventing its most serious injustices.

Moreover, I think that a critical approach must always be self-critical - it must recognize that how we make and apply legal theory arises out of the circumstances in which we recognize problems and articulate solutions. Theory may purport to be timeless, but what theory means in practice, how we should apply it, and which of its elements gain particular relevance, will change with changing times. A critical theory of law must recognize how different aspects of law-and of a critical theory of law itself-become newly salient or refigured in different circumstances, and how the seemingly timeless verities of one historical period are conditioned by the assumptions and expectations of that time. Critical legal theory is no exception. If a critical theory of law looks different today than it appeared thirty years ago, that is because the world itself looks different.

The critical project in American law arose in a unique period in American legal history. ${ }^{7}$ During the 1960 s American law had made enormous gains in promoting equality for the poor, for racial minorities, and for women, and greatly expanding the scope of civil liberties. In a few short decades the country had become far freer and more equal, and law - and the discourse of rights - had seemed to play an important part of the transformation. And when the Nixon Administration tried to subvert American democracy in the early 1970s, the

${ }^{7}$ For a similar accounts, which, however, draw different lessons for the present, see Louis Michael Seidman, Critical Constitutionalism Now, 75 FoRdHAm L. ReV. 575 (2006), and Mark Tushnet, Critical Legal Theory (Without Modifiers) in The United States, 13 J. PoL. PHIL. 99 (2005). 


\section{Critical Legal Theory Today}

Constitution and the rule of law seemed to provide key elements in the resolution of the crisis. Both the Watergate scandal and the Civil Rights Revolution seemed to demonstrate that law and rights discourse played an important role in promoting a just society. The law could not have succeeded without political mobilization and political will behind it. But law was a key institutional medium - and the language of rights a key discourse - through which progress was achieved.

But these gains - and the power of law to effect them - had stalled and slowed by the middle of the 1970s, due to a series of reactions and countermobilizations from different segments of society. The result was continuing improvement in some areas, retrenchment in others, and stalemate in still others. There was no promise anytime soon of another round of truly transformative changes toward greater liberty and equality. Instead, progress was halting and inconsistent.

The critical movements in American law arose in this period, when the liberatory edge of law had been blunted and the tectonic plates of American politics slowly shifted. From this perspective, key critical claims - that law reflected political struggles and political power, that rights discourse was manipulable and could easily be turned against progressive ends, and that legal argument often apologized for continuing injustices - made particular sense. As forces of reaction set in, the law once again appeared as a flexible tool of the powerful, and claims of law's impartiality a powerful rhetoric of mystification.

Critical scholars rebuked their liberal colleagues in the academy as apologists for a status quo that, they believed, still had far to go. Frustrated with law's inability to do good, and disgusted with complacent assertions of law's impartiality, they attacked the liberal defenders of the rights revolution and the rule of law as little better than their conservative adversaries. Whether or not this accusation was fair, it was surely deeply ironic. At this very moment in history the United States had already entered a period of political retrenchment, in which liberals would lose most of their influence and authority over the development of American law, although at the time people had no idea how long the period of retrenchment would last and how deep it would run. By directing their critical focus at the liberal legal academy, critical scholars ironically (and contrary to what their own theories would have advised) paid comparatively less attention to the most powerful forces in American society, forces that would significantly change the direction of law in the next several decades.

By the turn of the twenty-first century, new conservative social 
movements dominated American politics. Their agenda was very different from that of the progressive forces of the 1960's - indeed, it was in some sense a reaction to it. Today the critical project of debunking legal liberalism and rights discourse to clear space for greater justice seems beside the point. The problem today is not that liberal theories of law mask deep injustices, but that the rule of law itself has been cavalierly discarded in the quest for political power. The events of the early twentieth-first century have made the other side of the ambivalent conception of law particularly salient.

As the new century began, the Supreme Court of the United States settled a disputed Presidential election in Bush v. Gore ${ }^{8}$ by inventing a novel legal theory which did not even justify its remedy of stopping all recounts, and which, the Court suggested, it would be unlikely to apply to any future decisions. The reasoning was so weak and ad hoc by professional standards of legal argument that it appeared that the majority simply wanted to end the contested election in favor of the Republican candidate, George W. Bush.

Once in office, the Bush Administration's proclamation of a "war on terror" following the September 11, 2001 terrorist attacks made repeated assaults, some subtle, and some not so subtle, on key rule of law values of transparency, accountability and constraints on arbitrary power, particularly executive power. To give only a few examples: The Administration rounded up thousands of Arab and Muslim immigrants shortly after the 9/11 attacks and held them for months without charging them or disclosing their identities to the public. It held two American citizens in military prisons and claimed that they had no right to an attorney or to a judicial hearing to contest their designation as enemy combatants. Its secret Torture Memos justified torture and prisoner abuse by defining torture absurdly narrowly and by claiming presidential power to disregard statutes and treaties banning torture and cruel, inhuman, and degrading treatment. It maintained secret prisons overseas where it tortured and abused detainees, it sent others off to be tortured by different governments, and it stashed still others at Guantanamo Bay, Cuba to avoid the reach of American courts. It created military commissions to hold secret trials that permitted secret evidence the accused could not examine and secret witnesses whose identity the accused could not know. It began a series of secret and illegal domestic surveillance programs whose nature and scope it will not divulge, asserting that any attempt to litigate their validity would endanger national security and aid terrorists. And yet, as troubling as all these actions have been, the erosion of legal institutions may become far worse if Americans experience a second terrorist attack.

${ }^{8} 531$ U.S. 98 (2000). 


\section{Critical Legal Theory Today}

To be sure, one might insist that recent events have merely demonstrated conclusively that law was politics, that the rule of law was useless in combating injustice or constraining power, and that rights discourse was indeterminate and manipulable. $^{9} \quad$ Bush v. Gore did make legal arguments, even if they were transparently bad ones. Legal claims accompanied every incursion on American constitutionalism in the years following 9/11, and well-trained lawyers have been only too happy to justify the Bush Administration's every move - no matter how egregious - as fully consistent with the law. Indeed, government officials working in the Vice-President's office and in the Justice Department's Office of Legal Counsel developed novel legal theories claiming that when the President acted in his capacity in Commander-in-Chief, he could not constitutionally be bound by laws passed by Congress or by international human rights treaties. According to these theories, none of the President's actions were outside the law: rather the law effectively gave him the powers of a king or a dictator.

Moreover, in some cases the Administration did not even need to manipulate the law. It repeatedly used the threat of terrorism-- and accusations of being soft on terrorism-- to goad Congress into passing new laws that created military commissions, authorized searches without judicial supervision, abolished habeas corpus for suspected aliens, and expanded the government's powers of electronic surveillance.

Yet even while professional discourses and institutions of law assisted these actions, they also provided methods for restraining the Administration's worst excesses. Courts repeatedly rejected the President's most outrageous claims even if they upheld more modest powers. The professional discourse of law served as a partial check on executive aggrandizement. Perhaps equally important from the perspective of a critical theory, the political ideals of the rule of law - that legal institutions should restrain arbitrary power and impose norms of procedural fairness and impartiality - served as a powerful force both in American popular thought and in American legal culture. Whether or not any particular law or decision lived up to the ideals of the rule of law, both the American public and American lawyers and judges believed in those ideals. They fought back when they believed those values were threatened.

The ideals of human association embedded in the concept of the rule of law - like the ideals of liberty and equality - are well worth fighting for and realizing in our legal institutions, even (and especially) if we realize that all

\footnotetext{
${ }^{9}$ See Louis Michael Seidman, Critical Constitutionalism Today, supra.
} 


\section{Critical Legal Theory Today}

efforts to instantiate them in law are always subject to evasion, capture, and manipulation. In the world of the 1970s, critical theory noted how law failed when it was not supported by a robust politics; in doing so it deemphasized and marginalized the positive elements of law and legal culture that were always implicit in an ambivalent conception. But in a world of executive arrogance, authoritarian posturing, and blatant disregard for rule of law values, those elements must necessarily come to the fore in any critical account. Critical scholars have prided themselves on their deconstructive acumen - their ability to elucidate the hidden and marginalized values and assumptions that bodies of legal doctrine deemphasized but on which they secretly depended. We should apply those same deconstructive techniques to critical legal theory itself.

The focus of a critical approach to law-and its ambivalent conceptionwill inevitably shift as we introduce it into new contexts of judgment. Deemphasized aspects will emerge. Sometimes a critical approach to law will focus on how rule of law norms, legal institutions, and legal culture serve important political values; but not because law is independent from politics, or because law does not apologize for and legitimate injustices. Rather, legal culture and institutions are valuable to critical theories of law because they are a way of doing politics, in the sense of shaping, restraining and challenging power.

In like fashion, a critical approach will not view the rule of law as simply a formal legal principle - for example, the requirement that like cases must be treated alike. Nor should one confuse it with a formalist hope that if we design legal doctrines carefully enough, they can conclusively determine all important and contested cases or prevent all injustices and abuses. Rather, the rule of law, like liberty or equality, is a political value. It is a value one struggles for and struggles with. It demands that legal institutions and professional culture should work to restrain the arbitrary and unjust exercise of power, and that we should build, preserve and protect legal and social institutions to that end. Like most political principles, the principle of the rule of law does not determine the scope of its own extension; hence it can be fought over, and co-opted. But like other political principles — such as human dignity or equality - it is no less valuable to social life because it is underdetermined and co-optable.

History deconstructs; it shows how the conceptions of the past appear ever different in ever new contexts, how things we once thought naturally opposed are now joined together, and how things we thought were indelibly joined together now come apart. So it is with critical theories of law: in one era a critical approach lets us understand law's threat, in another, it reveals law's promise. The British historian E.P. Thompson famously argued that the rule of law was an 


\section{Critical Legal Theory Today}

unqualified human good. ${ }^{10}$ A unqualified good it will not be, at least to the ambivalent conception, for there always lurks the danger that law will become a form of idolatry and a technology of oppression. Yet there is no doubt that law and the rule of law are genuine human goods and indispensable elements in a humane civilization. It does not take a critical theory of law to recognize that fact. But without recognizing it, no theory of law can truly be critical.

\footnotetext{
${ }^{10}$ E.P. Thompson, Whigs AND HunTERs: The ORIGIN OF THE Black Act 266, 267 (1975); for a critique, see Morton J. Horwitz, The Rule of Law: An Unqualified Human Good?, 86 YALE L. J. 561, 566 (1977).
} 